\title{
GAYA PENGASUHAN OTORITER DAN PERILAKU BULLYING DI SEKOLAH MENURUNKAN SELF-ESTEEM ANAK USIA SEKOLAH
}

\author{
Andriansyah Adha Pratama ${ }^{1,2^{*}}$, Diah Krisnatuti ${ }^{3}$, Dwi Hastuti $^{3}$ \\ ${ }^{1}$ Program Studi IImu Keluarga dan Perkembangan Anak, Sekolah Pascasarjana, Institut Pertanian Bogor, \\ Bogor 16680, Indonesia \\ ${ }^{2}$ Indonesia Heritage Foundation, Depok 16951, Indonesia \\ ${ }^{3}$ Departemen IImu Keluarga dan Konsumen, Fakultas Ekologi Manusia, Institut Pertanian Bogor, \\ Bogor 16680, Indonesia \\ *) E-mail: syah081@gmail.com
}

\begin{abstract}
Abstrak
Penelitian ini dilakukan untuk menganalisis gaya pengasuhan orang tua, perilaku bullying di sekolah, dan self-esteem anak usia sekolah; perbedaan variabel berdasarkan jenis kelamin anak; hubungan antarvariabel penelitian; dan pengaruh karakteristik keluarga, karakteristik anak, gaya pengasuhan, dan perilaku bullying di sekolah terhadap self-esteem anak usia sekolah. Responden dalam penelitian ini adalah 100 orang siswa kelas IV dan V di tiga sekolah dasar negeri; sekolah ini berada di Kecamatan Ciracas, Jakarta Timur. Data dikumpulkan melalui pengisian kuesioner oleh anak. Analisis data menggunakan uji beda t, uji korelasi, dan uji regresi linear berganda. Gaya pengasuhan berhubungan signifikan dengan jenis kelamin anak. Anak laki-laki cenderung diasuh dengan gaya pengasuhan otoriter, sedangkan anak perempuan cenderung diasuh dengan gaya pengasuhan otoritatif. Berdasarkan persentase tertinggi, anak laki-laki cenderung menjadi pelaku bullying di sekolah, sedangkan perempuan cenderung menjadi korban bullying di sekolah. Gaya pengasuhan otoriter dan korban bullying verbal berpengaruh positif signifikan pada penurunan self-esteem anak. Hasil ini mengindikasikan bahwa penerapan gaya pengasuhan otoriter dapat menurunkan self-esteem anak. Anak yang menjadi korban bullying di sekolah juga dapat menurun self-esteem anak usia sekolah.
\end{abstract}

Kata kunci: anak usia sekolah, gaya pengasuhan otoritatif, gaya pengasuhan otoriter, perilaku bullying, selfesteem

\section{Authoritarian Parenting and Bullying in School Decrease Self-Esteem of School-Aged Children}

\begin{abstract}
This research was conducted to examine parenting style, bullying in school, and self-esteem of school-aged children; differences of these variables based on children sex; correlation among variables; and influence of family charactristics, children characteeristics, parenting style, and bullying in schools on self-esteem of schoolaged children. Particpants of this research were 100 students grade 4 and 5 of three public elementary schools; these schools were located in Ciracas Sub District, East Jakarta. Data were collected by self-report of participants. Data analysis used independent sample t-test, correlation test, and multiple regression analysis. The result showed that parenting styles had significant correlation with children sex. The boys tend to be raised with authoritarian parenting style; but the girls tend to be raised with authoritative parenting style. Based on the highest proportion, boys tend to bully others in school but girls tend to be victim of bullying. Authoritarian and victim of verbal bullying positive significantly influenced on decreasing of self-esteem. The result indicated that parents who conduct authoritarian style can cause decreasing self-esteem in school-aged children. The children who became victim of bullying in school also can decrease their self-esteem.
\end{abstract}

Keywords: authoritarian parenting style, authoritative parenting style, bullying, school-aged children, selfesteem

\section{PENDAHULUAN}

Kemajuan suatu bangsa ditentukan oleh kualitas dan kompetensi sumber daya manusianya. Salah satu sumber daya penting bagi kemajuan bangsa adalah anak. Anak memiliki potensi dasar yang dapat dikembang- kan dan diarahkan dengan baik. Pengembangan potensi anak menentukan kualitas anak. Anak yang berkualitas berperan penting dalam membangun bangsa. Hasil sensus penduduk tahun 2010 mencatat bahwa 34,26 persen dari jumlah seluruh penduduk Indonesia merupakan anak-anak dengan usia kurang dari 18 tahun. 
Sebanyak 27,3 juta jiwa diantaranya adalah anak usia sekolah. Usia sekolah yang dalam Papalia, Olds, dan Feldman (2004) dianggap sebagai usia pertengahan masa kanak-kanak merupakan titik penting untuk perkembangan fisik, kognitif, dan psikososial. Perkembangan anak pada usia ini menentukan kualitas anak pada tahap usia selanjutnya.

Menurut Goleman (1995), keberhasilan hidup seorang individu lebih ditentukan oleh kemampuan sosial dan emosi dibandingkan dengan kemampuan individual. Oleh karena itu, pengembangan aspek kepribadian seorang anak seharusnya menjadi prioritas utama dalam pembentukan generasi penerus yang berkualitas dan kompeten. Salah satu kemampuan sosial emosi anak yang perlu dikembangkan sehingga anak memiliki modal untuk menjadi manusia yang berkualitas dan kompeten adalah self-esteem.

Self-esteem merupakan penilaian umum seorang individu terhadap dirinya sendiri. Selfesteem berhubungan dengan kecerdasan sosial. Alfiasari, Latifah, dan Wulandari (2011) menemukan bahwa kecerdasan sosial semakin baik dengan semakin baiknya self-esteem. Latifah, Hernawati, dan Nurhayati (2011) juga menemukan bahwa semakin tinggi self-esteem seorang individu maka semakin baik perkembangan sosial dan emosi dari individu tersebut.

Salah satu lingkungan yang berperan penting dalam memberikan stimulasi untuk meningkatkan kualitas dan kompetensi anak adalah keluarga. Stimulasi yang diberikan oleh keluarga dilakukan melalui gaya pengasuhan. Menurut Baumrind (2008), gaya pengasuhan dikategorikan menjadi gaya pengasuhan tak terikat (unengaged), serba membolehkan (permissive), otoriter (authoritarian), dan otoritatif (authoritative). Gaya pengasuhan otoritatif adalah gaya pengasuhan yang baik yang menyeimbangkan antara disiplin dan kehangatan. Anak yang diasuh oleh orang tua dengan menggunakan gaya pengasuhan otoritatif cenderung memiliki perkembangan pola komunikasi conversation-orientation yang mendorong terbentuknya kelekatan dengan orang tua (Krisnatuti dan Putri, 2012). Gaya pengasuhan otoritatif juga meningkatkan self esteem dan kecerdasan sosial (Alfiasari, Latifah, dan Wulandari, 2011). Selain itu, gaya pengasuhan otoritatif juga berpengaruh positif pada konsep diri dan motivasi berprestasi (Rahmaisya, Latifah, dan Alfiasari, 2011). Dengan demikian, stimulasi dari keluarga melalui pengasuhan yang positif berperan penting dalam membentuk self-esteem remaja.

Salah satu tantangan yang harus dihadapi orang tua saat ini adalah bullying. Bullying merupakan perilaku yang menggunakan kekuasaan atau kekuatan untuk menyakiti seseorang atau sekelompok orang, suatu perilaku mengancam, menindas, dan membuat perasaan orang lain tidak nyaman. Bullying dapat berupa kontak fisik, verbal, dan nonverbal baik langsung maupun tak langsung. Hal yang lebih mengkhawatirkan adalah bullying di tingkat sekolah dasar lebih tinggi daripada di tingkat sekolah menengah (Dake, Price, dan Telljohann, 2003).

Indonesia juga menghadapi masalah bullying. Data Komisi Perlindungan Anak Indonesia (KPAl) menunjukkan bahwa pada tahun 2007 jumlah pelanggaran hak anak yang terpantau sebanyak 40.398 .625 kasus. Jumlah itu melonjak drastis jika dibandingkan dengan tahun sebelumnya yang mencapai 13.447.921 kasus. Berdasarkan data seluruh perilaku bullying terhadap anak, persentase terbesar yaitu 18,0 persen terjadi di rumah dan 11,3 persen terjadi di sekolah. Sementara itu, data dari forum Penanganan Korban Bullying Perempuan dan Anak (FPK2PA) Provinsi DIY di tahun 2011 menunjukkan bahwa dari total 367 kasus, 140 kasus merupakan perilaku bullying terhadap anak. Kondisi ini tentu meresahkan karena korbannya adalah generasi muda yang nantinya menjadi penerus bangsa. Penelitian sebelumnya menunjukkan bahwa bullying merupakan masalah serius karena bullying menurunkan self-esteem anak.

Self-esteem menjadi salah satu faktor yang menentukan kualitas anak. Oleh karenanya, kajian mengenai hal-hal yang dapat memengaruhi self-esteem perlu dilakukan. Penelitian sebelumnya telah menemukan adanya hubungan antara gaya pengasuhan dan bullying dengan self-esteem. Penelitian ini dilakukan untuk menganalisis gaya pengasuhan orang tua, perilaku bullying di sekolah, dan self-esteem anak usia sekolah. Perbedaan variabel berdasarkan jenis kelamin anak, hubungan antarvariabel penelitian, dan pengaruh karakteristik keluarga, karakteristik anak, gaya pengasuhan, dan perilaku bullying di sekolah terhadap self-esteem anak usia sekolah juga dianalisis dalam penelitian ini.

\section{METODE}

Penelitian ini menggunakan desain cross sectional. Penelitian dilakukan di tiga Sekolah 
Dasar Negeri yang berada di Kecamatan Ciracas, Jakarta Timur yang dipilih secara acak. Contoh dalam penelitian ini merupakan siswa kelas IV dan V dengan kondisi normal, artinya bukan anak berkebutuhan khusus (ABK) berdasarkan diagnosa psikolog dan/atau guru. Selanjutnya, siswa tersebut dikelompokkan berdasarkan jenis kelamin (laki-laki dan perempuan). Pemilihan contoh dilakukan secara acak berkelompok (cluster random sampling) yang terdiri atas 50 siswa laki-laki dan 50 siswa perempuan. Data primer yang dikumpulkan dalam penelitian ini meliputi karakteristik keluarga, karakteristik anak, gaya pengasuhan, perilaku bullying di sekolah, dan self-esteem anak. Data dikumpulkan melalui pengisian kuesioner oleh anak.

Gaya pengasuhan merupakan cara orang tua berinteraksi dan memperlakukan anaknya sehari-hari yang mana cara tersebut terbentuk secara psikologis, meliputi cara pendisiplinan, komunikasi, kehangatan, dan harapan. Dalam penelitian ini, gaya pengasuhan orang tua diperoleh dari hasil penilaian anak mengenai gaya pengasuhan yang diberikan orang tuanya. Kuesioner gaya pengasuhan orang tua menggunakan kuesioner yang disusun oleh Sari (2013). Kuesioner tersebut terdiri atas 38 pertanyaan dengan empat skala jawaban yaitu tidak pernah sama sekali (skor 1), jarang (skor 2), sering (skor 3), dan selalu (skor 4). Tiga jenis gaya pengasuhan dianalisis yaitu otoritatif (authoritative), otoriter (authoritarian), dan permisif (permissive). Skor yang diperoleh di setiap jenis gaya pengasuhan dijumlahkan. Skor tertinggi menunjukkan jenis gaya pengasuhan yang diterapkan orang tua.

Perilaku bullying di sekolah diukur menggunakan Olweus Bullying Questionnaire. Kuesioner terdiri atas 38 pertanyaan atau pernyataan dengan 4 skala jawaban, yaitu tidak pernah sama sekali (skor 0), jarang (skor 1), sering (skor 2), dan selalu (skor 3). Kuesioner ini memuat pertanyaan yang mengarah kepada korban bullying dan pelaku bullying. Setiap jawaban diberikan skor dan dijumlahkan pada masing-masing kelompok perilaku bullying. Selanjutnya, anak dikelompokkan menjadi pelaku atau korban berdasarkan skor yang diperoleh.

Kuesioner self-esteem yang digunakan adalah modifikasi dari Self-Esteem Inventory. Kuesioner ini terdiri atas 38 pernyataan dengan 4 skala jawaban yaitu tidak seperti saya (skor 1), agak seperti saya (skor 2), seperti saya (skor 3), dan sangat seperti saya (skor 4). Skor yang diperoleh dijumlahkan dan diubah menjadi bentuk indeks. Selanjutnya berdasarkan indeks, self-esteem dikategorikan menjadi rendah (indeks $<70$ ) dan tinggi (indeks $\geq 70$ ).

Data yang telah dikumpulkan diuji menggunakan uji beda $t$ (independent samples t-test), uji korelasi, dan uji regresi linear berganda. Uji beda $t$ dilakukan untuk menganalisis perbedaan variabel penelitian berdasarkan jenis kelamin anak. Uji korelasi dilakukan untuk menganalisis hubungan antarvariabel penelitian. Selanjutnya, uji regresi linear berganda dilakukan untuk menganalisis pengaruh karakteristik anak, karakteristik keluarga, gaya pengasuhan orang tua, dan perilaku bullying di sekolah terhadap selfesteem anak usia sekolah.

\section{HASIL}

\section{Karakteristik Anak dan Keluarga}

Rata-rata usia anak laki-laki lebih tinggi dibandingkan dengan rata-rata usia anak perempuan. Rata-rata usia ibu pada anak lakilaki lebih tinggi dibandingkan dengan rata-rata usia ibu pada anak perempuan. Sementara itu, rata-rata lama pendidikan ibu pada anak perempuan lebih tinggi dibandingkan dengan rata-rata lama pendidikan ibu pada anak lakilaki. Rata-rata pendapatan keluarga anak lakilaki lebih rendah dibandingkan dengan rata-rata pendapatan keluarga anak perempuan. Hasil uji beda yang disajikan pada Tabel 1 menunjukkan bahwa tidak terdapat perbedaan yang signifikan $(p>0,05)$ antara karakteristik keluarga anak lakilaki dengan anak perempuan. Selanjutnya, karakteristik keluarga juga dilihat berdasarkan status pekerjaan orang tua. Hasil penelitian menunjukkan bahwa sebagian besar status pekerjaan ibu dari anak laki-laki $(76,0 \%)$ dan perempuan $(70,0 \%)$ adalah tidak bekerja.

Tabel 1 Nilai rata-rata, standar deviasi, dan koefisien uji beda untuk karakteristik anak dan karakteristik keluarga

\begin{tabular}{lccc}
\hline \multirow{2}{*}{ Karakteristik } & \multicolumn{2}{c}{$\begin{array}{c}\text { Rata-rata } \pm \text { Standar } \\
\text { deviasi }\end{array}$} & $\begin{array}{c}p- \\
\text { value }\end{array}$ \\
\cline { 2 - 3 } & Laki-laki & Perempuan & \\
\hline $\begin{array}{l}\text { Usia anak } \\
\text { (tahun) }\end{array}$ & $11,1 \pm 0,7$ & $10,9 \pm 0,7$ & 0,461 \\
$\begin{array}{l}\text { Usia ibu } \\
\text { Lama }\end{array}$ & $41,1 \pm 4,6$ & $39,4 \pm 6,2$ & 0,123 \\
pendidikan ibu & $10,7 \pm 2,5$ & $11,7 \pm 3,3$ & 0,081 \\
(tahun) & & & \\
$\begin{array}{l}\text { Pendapatan } \\
\text { keluarga } \\
\text { (Rp000,00/ }\end{array}$ & $3.354,6 \pm$ & $3.488,8 \pm$ & 0,819 \\
bulan) & $3.037,7$ & $2.797,8$ & \\
\hline
\end{tabular}




\section{Gaya Pengasuhan Orang Tua}

Gaya pengasuhan orang tua terdiri atas gaya pengasuhan otoriter, permisif, dan otoritatif. Menurut Timpano et al. (2010), gaya pengasuhan otoritatif adalah gaya pengasuhan dengan tingkat kehangatan dan pendisiplinan yang tinggi. Orang tua memberikan peraturan dengan penjelasan logis serta mengutamakan kehangatan di dalam praktek pengasuhan. Selain itu, orang tua membuka ruang pendapat bagi anak mengenai peraturan yang berlaku sebagai masukan meskipun pendapat anak tersebut bertentangan dengan keinginan orang tua. Gaya pengasuhan otoriter merupakan gaya pengasuhan dengan tingkat kehangatan antara orang tua dan anak yang rendah namun dengan tingkat pendisiplinan yang tinggi (Timpano et al., 2010). Orang tua menerapkan peraturan tanpa kompromi dengan anak dan jika anak tidak mematuhi peraturan yang sudah ditetapkan maka anak akan mendapatkan hukuman. Selanjutnya, gaya pengasuhan permisif adalah gaya pengasuhan yang ditandai dengan tingkat kehangatan yang tinggi tetapi kontrol terhadap perilaku yang rendah (Timpano et al., 2010).

Sebagian besar orang tua dari anak lakilaki $(80,0 \%)$ dan juga orang tua dari anak perempuan $(96,0 \%)$ menerapkan gaya pengasuhan otoritatif. Gaya pengasuhan otoritatif $(p<0,01)$ berbeda signifikan antara anak laki-laki dan perempuan. Nilai rata-rata gaya pengasuhan otoritatif pada anak perempuan lebih tinggi dibandingkan dengan nilai rata-rata gaya pengasuhan otoritatif pada anak laki-laki. Gaya pengasuhan otoriter antara anak laki-laki dan perempuan juga berbeda signifikan $(p<0,05)$. Nilai rata-rata gaya pengasuhan otoriter pada anak laki-laki lebih tinggi dibandingkan dengan nilai rata-rata gaya pengasuhan otoriter pada anak perempuan. Sementara itu, penerapan gaya pengasuhan permisif antara anak laki-laki dan perempuan tidak berbeda signifikan $(p>0,05)$. Nilai ratarata, standar deviasi, dan koefisien uji beda untuk gaya pengasuhan orang tua pada anak laki-laki dan perempuan disajikan pada Tabel 2.

Tabel 2 Nilai rata-rata, standar deviasi, dan koefisien uji beda gaya pengasuhan orang tua

\begin{tabular}{|c|c|c|c|}
\hline \multirow{2}{*}{$\begin{array}{l}\text { Jenis gaya } \\
\text { pengasuhan }\end{array}$} & \multicolumn{2}{|c|}{$\begin{array}{c}\text { Rata-rata } \pm \text { Standar } \\
\text { deviasi }\end{array}$} & \multirow[t]{2}{*}{$p$-value } \\
\hline & Laki-laki & Perempuan & \\
\hline Otoriter & $32,3 \pm 6,7$ & $28,8 \pm 7,3$ & $0,014^{*}$ \\
\hline Permisif & $29,9 \pm 6,1$ & $31,0 \pm 4,8$ & 0,381 \\
\hline Otoritatif & $70,3 \pm 11,9$ & $78,2 \pm 11,9$ & $0,003^{\star *}$ \\
\hline
\end{tabular}

\section{Perilaku Bullying di Sekolah}

Hasil penelitian menunjukkan bahwa 74 persen anak laki-laki menjadi pelaku bullying di sekolah dan 26 persen lainnya menjadi korban. Jenis bullying yang dilakukan oleh anak laki-laki sebagai pelaku adalah bullying verbal $(89,2 \%)$. Selanjutnya, jenis bullying yang diterima oleh anak laki-laki sebagai korban adalah bullying nonverbal $(69,2 \%)$. Sementara itu, sebanyak 56 persen anak perempuan menjadi korban bullying di sekolah dan 44 persen lainnya menjadi pelaku bullying di sekolah. Jenis bullying yang diterima oleh anak perempuan sebagai korban adalah bullying nonverbal $(50,0 \%)$. Selanjutnya, jenis bullying yang dilakukan oleh anak perempuan sebagai pelaku adalah bullying nonverbal $(86,4 \%)$.

Nilai rata-rata pada anak laki-laki sebagai korban bullying fisik lebih tinggi dibandingkan dengan nilai rata-rata pada anak perempuan, sedangkan nilai rata-rata pada anak perempuan sebagai korban bullying verbal dan nonverbal lebih tinggi dibandingkan dengan nilai rata-rata pada anak laki-laki lebih rendah dibandingkan anak perempuan. Nilai rata-rata pada anak laki-laki dan perempuan sebagai korban bullying fisik, verbal, dan nonverbal tidak berbeda signifikan $(p>0,05)$. Nilai ratarata, standar deviasi, dan koefisien uji beda untuk korban bullying di sekolah disajikan pada Tabel 3.

Nilai rata-rata pada anak laki-laki sebagai pelaku bullying fisik, verbal, dan nonverbal lebih tinggi dibandingkan dengan nilai rata-rata pada anak perempuan. Nilai rata-rata untuk pelaku bullying fisik $(p>0,05)$, verbal $(p<0,01)$, dan nonverbal $(p<0,01)$ berbeda signifikan antara anal kali-laki dan perempuan. Nilai rata-rata, standar deviasi, dan koefisien uji beda untuk korban bullying di sekolah disajikan pada Tabel 3.

Tabel 3 Nilai rata-rata, standar deviasi, dan koefisien uji beda perilaku bullying di sekolah

\begin{tabular}{|c|c|c|c|}
\hline \multirow{2}{*}{$\begin{array}{l}\text { Perilaku } \\
\text { bullying di } \\
\text { Sekolah }\end{array}$} & \multicolumn{2}{|c|}{ Rata-rata \pm Standar deviasi } & \multirow{2}{*}{$p$-value } \\
\hline & Laki-laki & Perempuan & \\
\hline \multicolumn{4}{|c|}{ Korban bullying } \\
\hline Fisik & $23,7 \pm 16,4$ & $22,2 \pm 20,8$ & 0,690 \\
\hline Verbal & $21,6 \pm 14,0$ & $24,0 \pm 20,3$ & 0,484 \\
\hline Nonverbal & $27,9 \pm 16,6$ & $33,2 \pm 19,8$ & 0,148 \\
\hline \multicolumn{4}{|c|}{ Pelaku bullying } \\
\hline Fisik & $16,7 \pm 19,9$ & $8,0 \pm 14,4$ & $0,014^{*}$ \\
\hline Verbal & $46,0 \pm 14,1$ & $30,8 \pm 19,2$ & $0,000^{* *}$ \\
\hline Nonverbal & $26,3 \pm 13,3$ & $18,9 \pm 12,0$ & $0,004^{* *}$ \\
\hline
\end{tabular}


Tabel 4 Sebaran, nilai rata-rata, standar deviasi, dan koefisien uji beda untuk self-esteem anak laki-laki dan perempuan

\begin{tabular}{lrrr}
\hline \multicolumn{1}{c}{ Kategori } & \multicolumn{1}{c}{$\begin{array}{c}\text { Laki-laki } \\
(\%)\end{array}$} & $\begin{array}{r}\text { Perempuan } \\
(\%)\end{array}$ & \multicolumn{1}{c}{$\begin{array}{r}\text { Total } \\
(\%)\end{array}$} \\
\hline Rendah & 18,0 & 14,0 & 16,0 \\
Tinggi & 82,0 & 86,0 & 84,0 \\
Total & 100,0 & 100,0 & 100,0 \\
Rata-rata & $75,3 \pm 7,9$ & $76,6 \pm 6,1$ & \\
standar deviasi & & 0,346 & \\
p-value & & \\
\hline
\end{tabular}

\section{Self-Esteem Anak}

Tabel 4 menyajikan sebaran, nilai ratarata, standar deviasi, dan koefisien uji beda untuk self-esteem anak laki-laki dan perempuan. Self-esteem sebagai penilaian umum seorang individu terhadap dirinya sendiri (Santrock, 2007). Hasil penelitian menunjukkan bahwa lebih dari 80 persen anak baik yang berjenis kelamin laki-laki maupun perempuan memiliki self-esteem yang tinggi. Self-esteem yang dimiliki oleh anak laki-laki dan perempuan tidak berbeda signifikan ( $p>0,05)$.

\section{Hubungan Antarvariabel Penelitian}

\section{Hubungan antara karakteristik anak dan karakteristik keluarga dengan gaya pengasuhan orang tua. Uji korelasi menemukan bahwa usia anak, usia ibu, lama pendidikan ibu, status pekerjaan ibu, dan pendapatan keluarga tidak berhubungan signifikan $(p>0,05)$ dengan gaya pengasuhan ibu (gaya pengasuhan otoritatif, otoriter, dan permisif). Gaya pengasuhan orang tua berhubungan signifikan dengan jenis kelamin anak (laki-laki dan perempuan). Gaya pengasuhan otoritatif berhubungan signifikan positif dengan jenis kelamin anak $(r=0,301$, $p<0,05)$. Hasil ini mengindikasikan bahwa orang tua cenderung menerapkan gaya pengasuhan otoritatif pada anak yang berjenis kelamin perempuan. Sementara itu, jenis kelamin berhubungan signifikan negatif dengan gaya pengasuhan otoriter $(r=-0,282, p<0,05)$. Hasil ini mengindikasikan bahwa orang tua cenderung menerapkan gaya pengasuhan otoriter pada anak laki-laki.}

Hubungan antara karakteristik anak dengan perilaku bullying di sekolah. Uji korelasi menemukan bahwa usia anak tidak berhubungan signifikan $(p>0,05)$ dengan perilaku bullying di sekolah baik sebagai pelaku maupun sebagai korban. Jenis kelamin anak juga tidak berhubungan signifikan $(p>0,05)$ dengan perilaku bullying di sekolah dari sisi korban. Akan tetapi, jenis kelamin anak berhubungan signifikan dengan perilaku bullying di sekolah dari aspek pelaku bullying verbal $(r=-0,398, p<0,01)$ dan pelaku bullying nonverbal $(r=-0,253, \quad p<0,01)$. Hasil ini mengindikasikan bahwa pelaku bullying di sekolah cenderung dilakukan oleh anak lakilaki.

Hubungan antara gaya pengasuhan orang tua dengan self-esteem anak. Uji korelasi menemukan bahwa gaya pengasuhan otoritatif dan permisif tidak berhubungan signifikan dengan self-esteem anak. Selfesteem anak berhubungan signifikan dengan gaya pengasuhan otoriter $(r=-0,324, p<0,01)$. Hasil ini mengindikasikan bahwa self-esteem anak semakin menurun pada orang tua yang menerapkan gaya pengasuhan otoriter.

Hubungan antara perilaku bullying di sekolah dengan self-esteem anak. Uji korelasi menemukan bahwa perilaku bullying yang dilakukan anak di sekolah berhubungan signifikan dengan self-esteem anak sebagai korban bullying fisik $(r=-0,263, p<0,01)$, korban bullying verbal $(r=-0,381, \quad p<0,01)$, korban bullying nonverbal $(r=-0,238, p<0,05)$, pelaku bullying fisik $(r=-0,304, p<0,01)$, dan pelaku bullying nonverbal $(r=-0,267, p<0,01)$. Hasil ini menunjukkan bahwa anak yang menjadi korban dan pelaku bullying akan memiliki self-esteem yang semakin rendah. Dalam uji korelasi, pelaku bullying verbal tidak berhubungan signifikan dengan self-esteem anak $(p>0,05)$.

Pengaruh Karakteristik Anak, Karakteristik Keluarga, dan Gaya Pengasuhan terhadap Self-esteem Anak

Koefisien determinasi (Adjusted $R$ Square) untuk model persamaan regresi yang menganalisis pengaruh karakteristik anak, karakteristik keluarga, dan gaya pengasuhan terhadap self-esteem anak adalah 0,136. Nilai ini menunjukkan bahwa 13,6 persen varian selfesteem dapat dijelaskan oleh perubahan variabel yang terdapat pada model. Sisanya yaitu sebesar 86,4 persen self-esteem anak dipengaruhi oleh variabel lain yang tidak diteliti dalam penelitian ini. Hasil uji regresi linear berganda menunjukkan bahwa self-esteem anak dipengaruhi oleh gaya pengasuhan otoriter orang tua $(\beta=-0,334, \quad p<0,05)$ dan korban bullying verbal $(\beta=-0,211, \quad p<0,05)$. Koefisien regresi untuk menganalisis pengaruh karakteristik anak, karakteristik keluarga, dan gaya pengasuhan terhadap self-esteem anak usia sekolah disajikan pada Tabel 5 . 
Tabel 5 Koefisien regresi untuk menganalisis pengaruh karakteristik anak, karakteristik keluarga, dan gaya pengasuhan terhadap self-esteem

\begin{tabular}{|c|c|c|c|}
\hline Variabel bebas & $\mathrm{B}$ & $\beta$ & Sig. \\
\hline $\begin{array}{l}\text { Jenis kelamin anak } \\
\text { (0=laki-laki, } \\
1=\text { perempuan })\end{array}$ & 1,249 & 0,062 & 0,581 \\
\hline Usia anak (tahun) & $-1,828$ & $-0,122$ & 0,216 \\
\hline Usia ibu (tahun) & $-0,080$ & $-0,043$ & 0,669 \\
\hline $\begin{array}{l}\text { Lama pendidikan ibu } \\
\text { (tahun) }\end{array}$ & $-0,351$ & $-0,103$ & 0,318 \\
\hline $\begin{array}{l}\text { Status bekerja ibu } \\
\text { ( } 0=\text { =tidak bekerja, } \\
1=\text { bekerja) }\end{array}$ & 0,076 & 0,003 & 0,974 \\
\hline $\begin{array}{l}\text { Pendapatan keluarga } \\
\text { (Rp/bulan) }\end{array}$ & 1,800 & 0,052 & 0,610 \\
\hline $\begin{array}{l}\text { Gaya pengasuhan } \\
\text { otoritatif }\end{array}$ & 0,020 & 0,024 & 0,829 \\
\hline $\begin{array}{l}\text { Gaya pengasuhan } \\
\text { otoriter }\end{array}$ & $-0,344$ & $-0,243$ & $0,019^{*}$ \\
\hline $\begin{array}{l}\text { Gaya pengasuhan } \\
\text { permisif }\end{array}$ & $-0,075$ & $-0,041$ & 0,694 \\
\hline Korban bullying fisik & 0,026 & 0,047 & 0,752 \\
\hline Korban bullying verbal & $-0,211$ & $-0,361$ & $0,010^{*}$ \\
\hline $\begin{array}{l}\text { Korban bullying } \\
\text { nonverbal }\end{array}$ & $-0,007$ & $-0,013$ & 0,929 \\
\hline $\mathrm{F}$ & & & 2,300 \\
\hline Sig. & & & 0,013 \\
\hline$R$ & & & 0,241 \\
\hline Adjusted R Square & & & 0,136 \\
\hline
\end{tabular}

Hasil yang disajikan pada Tabel 5 menunjukkan bahwa gaya pengasuhan otoriter yang diterapkan orang tua berpengaruh signifikan negatif terhadap self-esteem anak. Hasil ini menunjukkan bahwa penerapan pengasuhan otoriter dapat menurunkan selfesteem anak. Perilaku bullying dalam hal ini adalah korban bullying verbal juga berpengaruh signifikan negatif terhadap self-esteem anak. Hasil ini mengindikasikan bahwa perilaku bullying verbal juga dapat menurunkan selfesteem anak.

\section{PEMBAHASAN}

Keluarga dan sekolah merupakan lingkungan terdekat dari anak usia sekolah. Dalam lingkungan keluarga, interaksi antara orang tua dan anak dapat terjadi melalui pengasuhan. Dalam penelitian ini, pengasuhan diukur berdasarkan gaya yang digunakan orang tua untuk mengasuh anak. Anak laki-laki cenderung diasuh oleh orang tua dengan gaya pengasuhan otoriter, sedangkan anak perempuan cenderung diasuh oleh orang tua dengan gaya pengasuhan otoritatif merupakan salah satu temuan dalam penelitian ini. Temuan ini sejalan dengan hasil penelitian yang telah dilakukan oleh Sari (2013). Sari (2013) mengungkapkan bahwa orang tua akan mengasuh anaknya lebih otoriter jika anak tersebut berjenis kelamin laki-laki.

Pada dasarnya, setiap anak memiliki hak untuk mendapatkan perlakukan yang sama dalam hal pengasuhan sebagaimana yang tertuang dalam Undang-Undang nomor 23 tahun 2002 tentang perlindungan anak. Akan tetapi, persepsi orang tua yang menganggap anak laki-laki harus lebih kuat dan tegas cenderung menyebabkan adanya perbedaan gaya pengasuhan yang diterapkan oleh orang tua untuk anaknya. Hal ini berdampak pada terjadinya perbedaan gaya pengasuhan yang diterapkan pada anak laki-laki dan perempuan.

Penelitian ini juga menemukan bahwa gaya pengasuhan otoriter dapat menurunkan self-esteem anak. Gaya pengasuhan otoriter didefinisikan sebagai gaya pengasuhan dengan tingkat kehangatan yang rendah dan tingkat pendisiplinan yang tinggi (Timpano et al., 2010), serta menuntut anak untuk patuh (Baumrind, 1991). Temuan ini sejalan dengan penelitian sebelumnya. Menurut Zhou et al. (2004) umumnya anak yang diasuh dengan gaya pengasuhan otoriter akan memiliki kemampuan sosial yang rendah dan kepercayaan diri yang rendah. Alfasari, Latifah, dan Wulandari (2011) juga menemukan bahwa gaya pengasuhan otoriter dapat menurunkan self-esteem anak, sedangkan gaya pengasuhan otoritatif dapat meningkatkan selfesteem anak.

Selain berdampak pada pengasuhan, penerapan gaya pengasuhan otoriter juga berdampak pada perilaku bullying. Penggunaan gaya pengasuhan otoriter akan mendorong anak untuk menjadi pelaku bullying. Menurut Dake, Price, dan Telljohann (2003), salah satu karakteristik pelaku bullying adalah memiliki orang tua yang mengasuh dengan gaya otoriter.

Lingkungan terdekat selanjutnya untuk anak usia sekolah adalah lingkungan sekolah. Di lingkungan sekolah, salah satu interaksi yang terjadi dan menjadi permasalahan global adalah perilaku bullying. Penelitian ini menemukan bahwa perilaku bullying berhubungan signifikan dengan jenis kelamin anak. Anak laki-laki cenderung menjadi pelaku bullying. Adanya hubungan antara jenis kelamin dan perilaku bullying si sekolah diungkapkan oleh Adilla (2009) melalui hasil penelitiannya yang menunjukkan bahwa pelajar laki-laki lebih 
sering melakukan tindakan bullying kepada pelajar lain daripada pelajar perempuan baik secara langsung maupun tidak langsung.

Berdasarkan korban bullying, hasil penelitian menunjukkan bahwa persentase anak laki-laki yang menjadi korban bullying fisik lebih tinggi daripada anak perempuan, sedangkan persentase anak laki-laki yang menjadi korban bullying verbal dan nonverbal lebih rendah dibandingkan anak perempuan. Hasil penelitian ini juga menunjukkan bahwa persentase korban bullying nonverbal lebih tinggi daripada persentase korban bullying yang lain, baik pada anak laki-laki maupun anak perempuan. Riauskina, Djuwita, dan Soesetio (2005) mengemukakan bahwa anak laki-laki yang menjadi korban bullying memiliki persepsi bahwa pelaku melakukan bullying karena balas dendam atas perlakuan yang sama. Sementara itu, anak perempuan yang menjadi korban memiliki persepsi bahwa pelaku melakukan bullying karena ingin menunjukkan bahwa pelaku memiliki kekuasaan, marah pada korban karena tidak berperilaku seperti yang diharapkan pelaku, pelaku mendapat kepuasan setelah melakukan bullying pada korbannya, serta iri hati.

Menurut Dake, Price, dan Telljohann (2003) salah satu indikator anak menjadi korban bullying adalah memiliki self-esteem yang rendah. Hasil penelitian ditemukan bahwa korban bullying baik fisik, verbal maupun nonverbal memiliki hubungan yang negatif signifikan dengan self-esteem anak perempuan. Hal ini berarti semakin meningkat perilaku bullying yang diterima anak perempuan maka self-esteem anak tersebut akan semakin rendah.

\section{SIMPULAN DAN SARAN}

Jenis kelamin anak berhubungan signifikan dengan gaya pengasuhan orang tua. Anak lakilaki cenderung diasuh secara otoriter, sedangkan anak perempuan cenderung diasuh secara otoritatif. Jenis kelamin anak juga berhubungan dengan perilaku bullying di sekolah, baik pada anak sebagai korban maupun pada anak sebagai pelaku. Anak lakilaki cenderung menjadi pelaku bullying di sekolah. Anak yang mengalami perilaku bullying di sekolah baik sebagi korban maupun pelaku memiliki self-esteem yang semakin rendah. Self-esteem anak menurun pada anak yang menjadi korban bullying di sekolah. Selfesteem juga menurun pada orang tua yang menerapkan gaya pengasuhan otoriter.
Gaya pengasuhan otoriter dapat menurunkan self-esteem anak. Oleh karenanya, orang tua hendaknya menghindari penggunaan gaya pengasuhan tersebut. Orang tua disarankan untuk mengubah gaya pengasuhan menjadi otoritatif. Selain itu, self-esteem juga menurun karena perilaku bullying di sekolah. Oleh karenanya, pihak sekolah hendaknya melakukan gerakan stop bullying di sekolah seperti memberikan perhatian yang lebih terhadap interaksi antar siswa terutama siswa laki-laki saat berada di luar jam pelajaran sekolah (seperti saat istirahat dan pulang sekolah), menanamkan pelajaran budi pekerti seperti menumbuhkan rasa empati, rasa kasih sayang dan toleransi baik secara langsung maupun terintegrasi dalam kegiatan di kelas.

\section{DAFTAR PUSTAKA}

Adilla, N. (2009). Pengaruh kontrol sosial terhadap perilaku bullying Pelajar di sekolah menengah pertama. Jurnal Kriminologi Indonesia, 5, 56-66.

Alfiasari, Latifah, W., \& Wulandari, A. (2011). Pengasuhan otoriter berpotensi menurunkan kecerdasan sosial, selfesteem, dan prestasi akademik remaja. Jur. IIm. Kel. \& Kons., 4(1), 46-56.

Baumrind, D. (1991). The influence of parenting style on adolescent competence and substance use. Journal of Early Adolescence, 11, 56-95.

Baumrind, D. (2008). Parenting for moral growth. The Counsil for Spiritual and Ethical Education. 1(2): 1-6

Dake, J. A., Price, J. H., \& Telljohann, S. K. (2003). The Nature and Extent of Bullying at school. Journal of School Health, 73, 173-180.

Goleman, D. (1995). Emotional intelligence. New York, US: Bantam Book.

Krisnatuti, D., \& Putri, H. A. (2012). Gaya pengasuhan orang tua, interaksi serta kelekatan ayah-remaja, dan kepuasan ayah. Jur. Ilm. Kel. \& Kons., 5(2), 101-109.

Latifah, M., Hernawati, N., \& Nurhayati, S. (2011). Kecerdasan emosional, kematangan sosial, self-esteem, dan prestasi akademik mahasiswa lulusan pesantren. Jur. IIm. Kel. \& Kons., 4(1), 6673.

Rahmaisya, R., Latifah, M., \& Alfiasari. (2011). Keseimbangan kehangatan dan kontrol orang tua menentukan konsep diri dan motivasi berprestasi atlet muda di sekolah 
berasrama. Jur. IIm. Kel. \& Kons., 4(2), 139-147.

Riauskina, I. I., Djuwita, R., \& Soesetio, S. R. (2005). "Gencet-gencetan" di Mata Siswa/Siswi 1 SMA. Jurnal Psikologi Sosial, 12, 1-13

Papalia, D. E., Olds, S. W., \& Feldman, R. D. (2004). Human Development ( $9^{\text {th }}$ ed.). New York, US: McGraw-Hill Book Company.

Sari, E. P. M. (2013). Pengaruh gaya pengasuhan ibu terhadap tingkat kreativitas siswa sekolah dasar progresif dan konvensional di Kota Depok (tesis).
Program Pascasarjana, Institut Pertanian Bogor.

Timpano, K. R., Keough, M. E., Mahaffey, B., \& Schmidt, N. B., \& Abramowitz, J. (2010). Parenting and obsessive compulsive symptoms: Implications of authoritarian parenting. Journal of Cognitive Psychotherapy: An International Quarterly, 24, 151-164.

Zhou, Q., Eisenberg, N., Wang, Y., \& Reiser, M. (2004). Chinese children's effortful control and dispositional anger/frustration: Relations to parenting styles and children's social functioning. Developmental Psychology, 40, 352-66. 